generation of internationalization specialists has significant potential to achieve these ends, building creatively and dynamically on all that has come before.

DOI: http://dx.doi.org/Io.6oI7/ihe.20I9.96.10772

\section{International Student Mobility in Israel}

\section{AN NetTe BAM BERGER}

Annette Bamberger is a PhD candidate at the Institute of Education, University College London, UK. E-mail: a.bamberger.14@ucl.ac.uk.

$\mathrm{W}_{\mathrm{p} \text { timata }}$ ith respect to research, Israeli universities have impressive international funding and publication and citation rankings; however, with respect to receiving international students, Israel performs poorly compared to the OECD average of 9 percent, with only I.4 percent of its student population coming from abroad. This has caused concern and attracted the attention of the Council for Higher Education (CHE) - Israel's central body charged with coordinating the higher education (HE) system-and of its funding arm, the Planning and Budgeting Committee (PBC). In a new multi-year plan announced in July 2017 , internationalization was identified as a key focus, with the goal of doubling the number of international students to 25,000 within five years.

\section{Historical Development and Contem porary Issues}

While the first students at Israeli universities in the preState era were predominantly from Eastern Europe, since the early decades of the State, most students in Israeli universities have been local. Due to the intractable Israeli-Palestinian conflict, regional student mobility to Israel is nearly nonexistent. Yet, international students have not been ignored. Starting in I955, international student programs targeting American Jewish students on a junior year/semester abroad were developed as a result of the coordination between universities, the government, and diaspora community organizations. In addition to the academic component (emphasizing the Hebrew language, Jewish studies, Israel studies, and Middle Eastern studies), cultural and social activities, tours throughout the country, and encounters with local Israelis also formed an integral part of the programs. Since the language of instruction in these programs was predominately English and students required specialized support (for visa, housing, etc.), separate infrastructures gradually developed to service these programs and students. While the programs were open to all, and international students from a variety of backgrounds welcomed, the programs were primarily targeted at a Jewish population, as demonstrated by marketing and recruitment; funding; support services; and formal and informal curriculum.

In contemporary times, international offerings at institutions have expanded to encompass short courses, summer programs, and degree-granting programs at the undergraduate, graduate, and doctoral levels. International degree-seeking students-at the bachelor's and master's (without thesis) levels - continue to be predominantly Jewish. While tuition paid by these students may represent revenue ventures for some institutions, the state, nonprofit organizations, and Jewish diaspora organizations provide students with financial support with an eye toward promoting solidarity, Jewish identity, and Israel-diaspora relations throughout the world.

\section{Due to the intractable Israeli-Palestin- ian conflict, regional student mobility to Israel is nearly nonexistent.}

In the past, Israel attracted an impressive proportion of the American study abroad population to these programs; in the I996 Open Doors report, Israel was the eighth most popular destination for study abroad for American students, with almost the same number of students studying in Israel $(2,62 \mathrm{I})$ as in all South America $(2,683)$. However, as international student mobility rapidly increased, Israel began to lose ground to other destinations and, in 20I7, Israel fell to an unranked position with 2,435 students. This decrease has multiple causes, including the precarious security situation. However, it is clear that Israel has not been able to maintain its competitive positioning in the United States.

In addition to the traditional Jewish population in international programs, Israel has also fostered exchanges and partnerships for student mobility, particularly with countries of strategic economic and political importance. Beginning in 2008 with the opening of a national Tempus office and the subsequent expansion of Erasmus +, there has been an influx of European students to Israeli campuses; in 20I5-20I7, the Erasmus + program brought 2,47I students and staff from the European Union to Israel. Furthermore, since 20I2, there have been significant government initia- 
tives to bring closer collaboration with China and Indiaincluding sponsorship of Chinese and Indian research students (master thesis, $\mathrm{PhD}$, and postdoctorate)-with academic cooperation forming a basis for partnership.

The new multi-year plan of the CHE builds on these patterns and aims to expand the intake of two categories of international students: I) excellent research students with a special focus on China and India; and 2) excellent Jewish students, particularly from the United States and Canada. Policy documents and reports emanating from the CHE reveal the drivers behind these new policies: Israel hopes to build close economic and political relationships with these countries, while strengthening the academic level of its higher education institutions and its R\&D capabilities to compete in the "global knowledge economy." It is conspicuous that motives of peace building and cross-cultural understanding are absent, despite the ongoing conflict. The overall outcome is that Israel has an internationalization policy containing two distinct strands: research students, particularly from countries with which Israel wants to improve economic and political ties; and students from the Jewish diaspora, connecting to the identity of the state as the Jewish homeland. This is reflected in the latest CHE statistics from 2016 , which show that, overall, there are slightly more Jewish $(5,370)$ than non-Jewish students $(4,700)$ in Israel, and that there is a clear split between the research and nonresearch tracks. Research students (master with thesis, $\mathrm{PhD}$, and postdoctorate) are predominantly non-Jewish, while Jewish students are predominantly in nonresearch tracks (study abroad, BA, taught master).

\section{Challenges}

In the current plan, a number of issues receive insufficient attention, such as the historical infrastructures for international students and the potential challenges of attracting and supporting different types of students, and there is little guidance about how the two strands should be managed. The two target groups-with different normative references and personal, ethnic, and religious connections to the country-will pose a challenge to Israeli universities trying to attract, accommodate, and support both groups. In line with institutional missions, there is evidence that some universities are focusing on one group. According to a report from the CHE in 20I6, the Weizmann Institute of Science, a research institution, has the lowest percentage of Jewish students, while IDC Herzliya—which specializes in bachelor and taught master programs - has the largest Jewish student population. Universities aiming to attract both populations and with substantial concentrations of both populations may face the greatest challenges in developing a comprehensive internationalization strategy. Will the new international student scheme be a success? Will there be a (further) specialization (and separation) in "research" and "nonresearch" international students? And in this case, is this not a missed opportunity to bridge and reimagine international higher education in Israel?

DOI: http://dx.doi.org/Io.6oI7/ihe.2019.96.10774

\section{Italy: Brain Drain or Brain Circulation?}

\section{Chantal Saint-Blancat}

Chantal Saint-Blancat is a former associate professor of sociology at the University of Padua, Italy. E-mail: chantal.saint-blancat@unipd.it.

$\mathrm{F}$ or scientists, mobility has always been evident, as research has no boundaries. International scientific mobility has notably increased in recent times with the globalization of knowledge. At present, Europe is a paradigmatic case. In the past decade, EU policy has shaped, and strongly promoted, scientific and educational mobility by means of the Marie Curie Fellowship Scheme and other scientific grants managed by the European Research Council. Yet, brain circulation involves fierce competition and there is a risk of a growing concentration of "bright minds" in countries that have dedicated more attention and resources to scientific research, such as Germany or the United Kingdom, at the expense of others such as Greece, Italy, or Spain. The EU's open labor market can easily transform itself into a brain-drain/brain-gain situation. In such a context, the Italian case study is particularly noteworthy. Recent data indicates that Italy has an outgoing flow of scientists, that few of them return, and that, unlike other countries, Italy cannot count on an incoming flow of foreign scientists to replace them.

Research funded by the University of Padua and conducted between September 20I3 and July 20I5 shows relevant results on the complexity of scientific mobility, adding evidence to the existing theory on brain drain and brain circulation. The study drew on 83 in-depth interviews conducted with Italian scientists (mathematicians, engineers, and physicists) working in Europe and on the results of a subsequent survey based on computer-assisted web interview questionnaires sent to 2,420 Italian scientists (gener- 